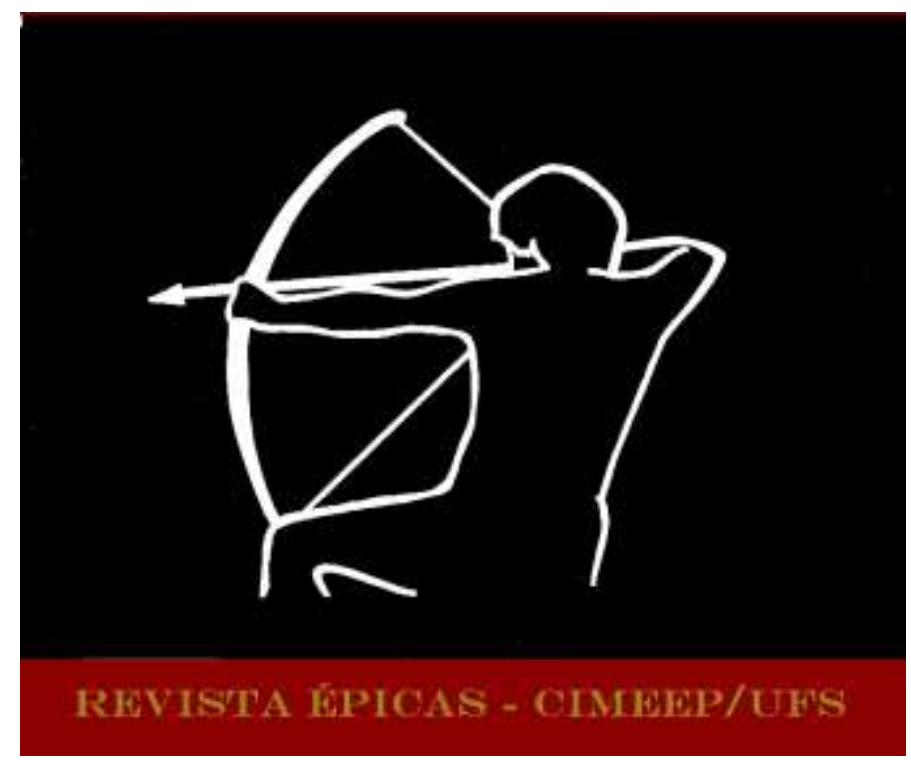

RITA, Annabela. Régio, 50 anos depois, ao espelho das Artes e das Letras. In: Revista Épicas. Ano 4, N. 7, Jun 2020, p. 1-13. ISSN 2527080-X.

\title{
RÉGIO 50 ANOS DEPOIS, AO ESPELHO DAS ARTES E DAS LETRAS
}

\author{
RÉGIO 50 YEARS LATER, \\ TO THE MIRROR OF ARTS AND LETTERS
}

\section{Annabela Rita}

Universidade de Lisboa-FL-CLEPUL

RESUMO: A partir de alguns textos representativos e de diferente genologia de José Régio, pretende-se, com este artigo, observar o modo como a autorrepresentação autoral se funde com a representação da identidade nacional, ou se constitui sua figuração, entretecendo as componentes (auto)biográfica, filosófica, nacional e estética. Assim, o sujeito poético tende a projectar-se em imagens fusionais que vibram no diálogo das Artes e das Letras, convocando a memória colectiva para nela se inscrever autoralmente, articulando tradição e inovação, ética e estética, nacional e individual, vida e morte, liberdade e fatalidade, etc..

Palavras-chave: Régio; Arte; (Auto-)representação; Cânone; Identidade; Comunidade.

ABSTRACT: Based on some representative texts and of different genology by José Régio, this article intends to observe the way in which authorial self-representation merges with the representation of national identity, or constitutes its figuration, interweaving the (self) components biographical, philosophical, national and aesthetic. Thus, the poetic subject tends to project itself into fusion images that vibrate in the dialogue between Arts and Letters, calling on collective memory to authorally inscribe itself, articulating tradition and innovation, ethics and aesthetics, national and individual, life and death, freedom and fatality, etc.

Keywords: Régio; Art; (Self-) representation; Canon; Identity; Community. 
A Jacinto do Prado Coelho (1920-84), meu professor e quase orientador, que me propôs para tese de mestrado a Confissão dum homem religioso - páginas íntimas (1971). Perdido o Mestre, não segui a sugestão, mas evoco-o aqui com saudade.

"O sol fundira em oiro a névoa fria; Num banho de oiro, a terra jaz, prostrada;

Já, no céu roxo, o sol, que ardeu, se esfria; Cai, no silêncio, a tarde repousada;

No ar molhado e absorto, ascende a lua;

...Até que fala Alguém a quem não minto: José Régio ("Pobres")

Sob a luminosidade indecidível de Impressão $(1972)^{1}$, de Claude Monet, culminar de uma série de levants e de couchants de soleils de Eugène Delacroix, Eugène Boudin, Johan Barthold Jongkind ou William Turner2, "L'après-midi d'un faune” (1876), de Stéphane Mallarmé, ilustrado por Édouard Manet, monólogo sobre o onírico e sensual despertar de um fauno após os seus encontros com ninfas, constituiu-se como texto simbólico e expressivo de uma modernidade estética dominada pelo olhar ébrio e reflexivo, em simultâneo, beirando abismos de alucinação e espanto. Fauno com tão diversa e vasta configuração estética numa linhagem que passa por autores como Agostino Carracci (1557-1602), Filippo Lauri (1623-1694), Arnold Böcklin (1827-1901), Peter Basin (1793-1877), Karl Friedrich Schinkel (1781-1841), Carlos Schwabe (1866-1926) até Débussy. E Claude Debussy ritmou-lhe o sonolento despertar em Prélude à l'après-midi d'un faune ( 1892-94), mote do bailado L'après-midi d'un faune de Vaslav Nijinsky ${ }^{3}$, que os coreografou para os Ballets Russes e protagonizou na sua estreia (Théâtre du Châtelet, Paris, 1912)... A imagem parece flutuar no diálogo das artes, associada, também, ao almoço na relva de Manet (1862-63), tão convocador de longa anterioridade pictórica (de

\footnotetext{
1 Que adquire o subtítulo no catálogo: Claude Monet: "Impressão, nascer do sol", obras-primas impressionistas. Collectible Card Series. Atlas Kustannus, 1994/1997. Depois, observar-se-á uma oscilação entre a interpretação de sol nascente ou pôr-so-sol.

2 Robert Schnerb, Le XIXe siècle. L'apogée de l'expansion européenne (1815-1914), Presses universitaires de France, 1955, p. 218. Depois, outros os tematizarão, como Monet (Soleil couchant sur la seine à Lavacourt, effet d'hiver,1880, Pont de Waterloo: soleil à travers le brouillard, 1903).

${ }^{3}$ Coreografado por Vaslav Nijinski para os Ballets Russes.
} 
Giorgione a Ticiano e Rafael, dentre outros) ${ }^{4}$ e que tantos celebraram com homólogos (desde Cézanne, Monet, Gauguin, Hugues ou Tissot até Max Ernst e Picasso), até noutras artes (a novela L'Oeuvre, 1885-86, de Émile Zola, e o filme de Jean Renoir, em 1959).

Será no quadro dessa indecidibilidade perceptiva de quando "O sol fundira em oiro a névoa fria" que o verbo regiano acolherá, fusionalmente, as representações de si e do mundo, de si no mundo, do mundo em si, mas também de um além e aquém de si e do real tangível. Representações por onde se insinua, em fantasia dramática de baile de máscaras evocadoras da velha Commedia dell'arte ("Três Máscaras"5), um "poeta infeliz"-Pierrot", máscara cuja progressiva transparência deixará perceber o rosto...

Revisitemos José Régio (1901-1969) em dupla autorrepresentação: a comunitária e a individual que dela emerge e nela se inscreve. ${ }^{7}$ Sempre, talvez, sobreimpressa no modelo cristológico que atravessa a cultura portuguesa e informa as obras de alguns autores maiores do nosso cânone: o da sua identificação com o arquetípico Filho do Homem (1961), como o sinalizam a epígrafe de Poemas de Deus e do Diabo, retirada da Imitação de Cristo ("Neste abismo é que tu me fazes conhecer a mim mesmo.") e a imensa colecção de crucifixos em que se envolveu, como se fossem o seu Sudário de espinhos... bem o insinua Ventura Porfírio no retrato Poeta de Deus e do Diabo (Casa Museu de Portalegre), onde o cone luminoso projecta o modelo religioso nas mãos escreventes do nosso autor, assumidamente auto-representado em Biografia (1929, poesia), Confissão dum homem religioso - páginas íntimas (1971) e em Páginas do diário íntimo (1994), em especial.

\title{
(Auto)biografia
}

\author{
"O Fado nasceu um dia, \\ quando o vento mal bulia \\ e o céu o mar prolongava, \\ na amurada dum veleiro, \\ no peito dum marinheiro
}

\footnotetext{
${ }^{4}$ A Tempestade (c. 1508). de Giorgione, O Concerto Campestre (c. 1510), de Giorgione ou Ticiano, a gravura do Julgamento de Paris (c. 1515), de Marcantonio Raimondi com desenho de Rafael, Bacanal (between 1627 and 1628), de Nicolas Poussin, La Partie Carrée, (c. 1713), de Antoine Watteau.

${ }^{5}$ Originalmente publicado na presença (1934), depois, ampliado, e reunido a "O Meu Caso" e "Mário ou Eu Próprio - o Outro" na coletânea Três Peças em um Acto (1957). Cf. Maria José M. Madeira D'Ascensão (PDF) Entre a Identidade e a Máscara: um Estudo de "Três Máscaras " de José Régio [https://www.researchgate.net/publication/296637979_Entre_a_Identidade_e_a_Mascara_um_Estudo_de_Tres_ Mascaras_de_Jose_Regio].

${ }^{6}$ José Régio, "Três Máscaras", Obra Completa: Teatro II, Lisboa, INCM, 2005, p. 261.

7 José Régio. Poesia I, Obra Completa, Lisboa, Imprensa Nacional-Casa da Moeda, 2004. Contém os livros Poemas de Deus e do Diabo (1925), Biografia (1929), As Encruzilhadas de Deus (1936), Fado (1941) e um estudo introdutório de José Augusto Seabra, "José Régio, Um Poeta em Estado Místico". Poesia II, Obra Completa, Lisboa, Imprensa NacionalCasa da Moeda, 2001. Contém os livros Mas Deus É Grande (1945), A Chaga do Lado (1954), Filho do Homem (1961), Cântico Suspenso (1968), Música Ligeira (volume póstumo, 1970) com notas de Alberto de Serpa, Colheita da Tarde (volume póstumo, 1971) organizado e anotado por Alberto de Serpa e 16 Poemas Não Incluídos em Colheita da Tarde (volume póstumo, 1971) com proémio e notas de Alberto de Serpa.
} 
que, estando triste, cantava, que, estando triste, cantava."

Fado Português ${ }^{8}$ José Régio

"Fado Português", de Régio. Musicado por Alain Oulman e cantado pela voz dolente de Amália (Fado Português, 1965) ${ }^{9}$ e, mais tarde, por Mariza e Dulce Pontes (Álbum Caminhos) ${ }^{10}$, evocadas por Fernando Pereira ${ }^{11}$, balançado ao ritmo dos ventos da saudade sombreada em Barco Negro nas vozes de Amália (1955), Mariza (2001), Ney Matogrosso e tantos outros... eis a história de uma identidade colectiva em que a individual se projecta e inscreve, marcada pelo mesmo tónus, pela mesma tragicidade, pela mesma ânsia batida pelos limites. Eis a versão regiana desse "fado português" (Património Imaterial da Humanidade da UNESCO desde 2011) bebido na "Nau Catrineta" da memória colectiva multiplamente revisitada e reconfigurada ${ }^{12}$ na sua irresistível hermenêutica da História de Portugal, como acontece, com Almada, "Futurista e tudo...", que nos oferece, como última imagem de que partia além-mar ou de lá chegava, memento de uma identidade, o seu tríptico "Lá vem a Nau Catrineta, que tem muito que contar" da Gare de Alcântara (1943): imagem de outrora em que o agora do visitante se projecta numa imagem fusional de um outroragora nacional singular ("Lá vem a nau Catrineta que tem muito que contar! Ouvide, agora, senhores, uma história de pasmar") ${ }^{13}$. Imagem confirmando um pacto selado em Ourique e heraldicamente codificado em bandeira assim desafiadoramente erguida em finisterra europeia na recta final do ciclo bélico das 2 Guerras Mundiais. "Nau Catrineta" musicada e cantada após a revolução dos cravos, por Fausto Bordalo Dias (1979) ${ }^{14}$, Vitorino (1991) $)^{15}$, Paulo Bragança $(1992)^{16}$, Nuno da Câmara Pereira $(2018)^{17}$ e outros $^{18}$. "Nau Catrineta" cujas velas sopradas pelos ventos da saudade dos que ficam e dos que partem embebe as artes nacionais, instituindo-se uma forma de arte de ser português, arte perscrutada

\footnotetext{
8 https://natura.di.uminho.pt/ jj/musica/html/amalia-10.html.

${ }^{9} \mathrm{Cf}$. https://www.youtube.com/watch?v=qbuF8wfOWL4. Foi o único poema de José Régio interpretado por Amália, mas Vitor Pavão dos Santos considerava que enunciava o modo como ela encarava o fado." (O fado da tua voz. Amália e os poetas, Lisboa, Bertrand Editora, 2014).

${ }^{10} \mathrm{Cf}$. Álbum Caminhos: https://www.youtube.com/watch?v=wIOTiqrgd94.

${ }^{11} \mathrm{Cf}$. https://www.youtube.com/watch?v=JscJxYUGbz8.

12 Garrett. Romanceiro de Almeida Garrett. S.I.: Ulisseia, 1997, pp. 354-355. Almeida Garret recolheu o poema, acreditando referir-se ele a viagem que, em 1565, trouxe Albuquerque Coelho de Olinda (Brasil) para Lisboa

${ }^{13} \mathrm{Cf}$., dentre muitos estudos sobre o assunto: Vilma Fernanda Séves de Albuquerque Silvestre. O fado e a questão da identidade, Lisboa, Universidade Aberta, 2015 [https://repositorioaberto.uab.pt/bitstream/10400.2/4837/1/TD_VilmaSilvestre.pdf]

${ }^{14}$ Do álbum Histórias de Viageiros (1979) [https://www.youtube.com/watch?v=EDF9rEv9dbw]

15 Álbum Nau Catrineta · Lua Extravagante (1991).

16 No álbum Camões, As Descobertas... E Nós (1992), de José Cid e outros.

17 Álbum Nau Catrineta (2018).

18 Síntese da fábula da "Nau Catrineta" por Luísa Antunes em http://multimediausaz.blogspot.pt: e https://www.youtube.com/watch?v=IpPRBY6bByU.
} 
por Pascoaes (1915) e caricaturada por Alberto Pimenta $(1978)^{19}$ sob esse título. Um nacional folheado por Régio em Fado (1941).

No "Fado Português", Régio-marinheiro, saudoso da sua origem ("Ai, que lindeza tamanha,/ meu chão, meu monte, meu vale,/ de folhas, flores, frutas de oiro"), geográfica e cultural, com ecos da trovadoresca canta em "frágil veleiro" "a canção magoada" "dos desejos" pungentes, "do lábio a queimar de beijos/ que beija o ar, e mais nada"... Régio respondendo a outro marinheiro velando "à proa de outro veleiro", "que, estando triste, cantava", sempre rejeitando o pacto faustiano ("Que minh'alma é só de Deus,/ O corpo, dou-o eu ao mar"), autor a outros respondendo numa cultura encarada como a never ending conversation (Wendy Steiner)...

Trata-se de uma figuração complexa num complexo sentimento europeu que Portugal, frente avançada dessa Europa aventurosa de que é "cabeça" (Camões) ou "rosto" (Pessoa), sua sinédoque, protagoniza, simboliza e refracta. E trata-se, também, de auto-representação regiana.

Europa, princesa fenícia dos velhos mitos, vai dando origem a renovado e metamórfico imaginário onde a tópica da aventura e do mar se mantém. Como profecia (Europa uma Profecia, 1794, de William Blake), glosada pelas suas nações, como Portugal, que alinha na sua bibliografia A chave dos Profetas e História do Futuro (séc. XVII), de António Vieira, Os Lusíadas (1572), Peregrinação (1614), a História Trágico-Marítima (1735), a Mensagem (1934), etc.. Ou Uma Aventura Inacabada (2004) para Zygmunt Bauman. Ou uma ideia, como para George Steiner (A Ideia de Europa, 2004). Ou os seus mitos, como destaca Vasco Graça Moura (A Identidade Cultural Europeia, 2013). Ou os valores e ideais que concebeu e elaborou: hoje, em irreconhecimento, como defende Rob Riemen (O Regresso da Princesa Europa, 2016). Ou moribunda, como anuncia Douglas Murray (A Estranha Morte da Europa, 2017). Ou... no cruzamento de outrora em que o destino de Édipo consumou a 1a parte, o sentimento é sempre contraditório e complexo.

Deitada nos mapas antropomórficos, a Europa observa o continente seguinte, África, e o espelho oceânico em que o infinito se projecta. E confronta, reflexivamente, a Esfinge dos enigmas existenciais... Pensadora diante de outra. E, se o abismo oceânico the devolve uma imagem invertida, especular, a extensão continental oferece-lhe refracções de si, replicada na topografia diversa e nas nacionalidades que nesta vão emergindo, como é o caso de Portugal.

\footnotetext{
${ }^{19}$ Refiro-me à série televisiva de 10 episódios da RTP 1, que, em 1978, caricaturou os costumes e os vícios portugueses através de episódios ficcionais encenados [https://arquivos.rtp.pt/conteudos/arte-de-ser-portugues-episodio-1/].
} 
Uma Europa ao espelho. Tópica da Arte renascentista, que configurou o seu ideal e medida de beleza numa Vénus na sua toilette (Rodin, Boucher, Lemoyne, Réattu, Cazes, Bouguereau, Bénard, Callet, Fantin-Latour, Regnault, etc.). Por vezes, uma Vénus a observarnos, dissimuladamente, através do espelho, como no caso da de Diego Velázquez (A Toilette de Vénus, $1647-51)^{20}$, alongada de costas em pose sensual diante de um espelho que Cupido the segura, ou como a de Peter Paul Rubens (Vénus ao espelho, c. 1614-15).

Num Portugal sinedóquica, replicante e simbolicamente encarado como frente avançada da Europa aventurosa, eis um sinal dessa identidade continental face ao mar no painel Vasco da Gama e Tétis observando a Máquina do Mundo, por Almada Negreiros (1961) ${ }^{21}$, na entrada da Faculdade de Letras de Lisboa, evocando o episódio camoniano da épica (Os Lusíadas), na confluência de longa linhagem da descoberta do mundo ${ }^{22}$. Linhagem projectandose no já referido tríptico da "Nau Catrineta" de Almada, sobre uma comunidade entre sagrado, profecia e utopia, por cujos painéis o Anjo Custódio desliza, salvando o capitão que não aceita o pacto com o Diabo... A essa linhagem (cor)responde Régio com o seu "Cântico Negro" (1926) de Poemas de Deus e do Diabo (1951), hermenêutica, também, da existência que encara como luta entre luz e sombras ("Deus e o Diabo é que guiam, mais ninguém.") vigorosamente dito pelo próprio ${ }^{23}$ e por João Villaret ${ }^{24}$, femininamente assumido por Maria Bethânia $(1982)^{25}$, revisitado em sessão de Prémio Autores 2017 por Pedro Lamares ${ }^{26}$ :

Não, não vou por aí! Só vou por onde Me levam meus próprios passos... ${ }^{27}$

N'A Velha Casa (5 romances, 1945-66) ${ }^{28}$, configura-se um mundo em que a ficção autobiográfica dialoga com Páginas do Diário Íntimo e Confissão dum Homem Religioso, mas

\footnotetext{
${ }^{20}$ Natasha Wallace defende não visar o retrato nem o mito, mas de constituir uma imagem da beleza absorta em si mesma (Natasha Wallace,."Venus at her Mirror" (17 de novembro de 2000). JSS Virtual Gallery [http://jssgallery.org/Other_Artists/Velazquez/Velazquez_Venus_at_her_Mirror.htm]

${ }^{21} \mathrm{Cf}$. Reis 2008.

22 O Tratado da Sphera de Pedro Nunes (1537) terá sido a fonte astronómica principal de Camões. O Tratado da Sphera de Pedro Nunes contém cinco tratados, dois de sua autoria e três traduzidos do latim - De Sphaera de Sacrobosco (1472), Theoricae Novae Planetarum de Purbáquio (1460) e a Geografia de Ptolomeu (Séc. II). De Sphaera de Sacrobosco foi traduzido para português por diversas vezes, mas a versão de Pedro Nunes contém muitas anotações escritas nas margens das páginas, explicando, completando ou corrigindo Sacrobosco. Em caso de divergência de opinião, Camões segue as anotações de Pedro Nunes, e não o texto original de Sacrobosco, sinal inequívoco da actualidade da sua cultura científica...

${ }^{23} \mathrm{Cf}$. https://www.youtube.com/watch?v=TBCd0vuxbFo

${ }^{24} \mathrm{Cf}$. https://www.youtube.com/watch?v=T2oQYkQrAr8\&t=61s

${ }^{25} \mathrm{Cf}$. https://www.youtube.com/watch?v=XV_iXZFPBCk

${ }^{26} \mathrm{Cf}$. https://www.youtube.com/watch?v=py7oZkL1MoQ

27 https://viciodapoesia.com/2012/03/05/cantico-negro-de-jose-regio-1901-1969/

28 I - Uma Gota de Sangue, 1945; II - As Raízes do Futuro, 1947; III - Os Avisos do Destino, 1953; IV - As Monstruosidades Vulgares, 1960; V - Vidas são Vidas, 1966).
} 
também com a lírica regiana, em geral, para fundir num mesmo sujeito, destino e sentimento um eu na linhagem de outros que vocalizaram o ser-sentir-fazer de um Portugal em devir... e de um sujeito autoral nele refractado ${ }^{29}$. E a casa regiana dialoga com tantas que a precedem e the sucedem nessa representação: desde as dinisianas (em especial o díptico Uma Família Inglesa, 1867, Os Fidalgos da Casa Mourisca,1871), onde se efabulam e simbolizam projectos nacionais inter-classes, ao queirosiano Ramalhete d'Os Maias (1888), passando pela de Érico Veríssimo (Tempo e o Vento: O Continente, 1949, O Retrato, 1951, e O Arquipélago, 1961) à aquiliniana (A Casa Grande de Romarigães (1957), às de Carlos de Oliveira ou à fantástica Torre de Rúben A. (A Torre da Barbela, 1965), à metamórfica de Teolinda Gersão (1995) ou à de Mia Couto (Um Rio Chamado Tempo, uma Casa Chamada Terra, 2002), para apenas mencionar algumas referências em língua portuguesa...

Régio epigrafa a sua Biografia (1929) com Nietzche: "Quando se ama o abismo,/ é preciso ter asas". Serão essas asas a identificá-lo no "Epitáfio do Poeta" (p.175-176), insinuando, quiçá, a aproximação às configurações angélicas da nação (Anjo de Portugal) e da poesia desse rosto "que fita" "com olhar esfíngico e fatal,/ O Ocidente, futuro do passado":

$$
\begin{aligned}
& \text { O arcanjo de asas pandas de granito } \\
& \text { Poisa um dedo no lábio concentrado; } \\
& \text { Mantém-se hierático e de pé, gelado; } \\
& \text { E o seu olhar de pedra é alheio e fito }{ }^{30} \text {. }
\end{aligned}
$$

E se, no "Epitáfio para um Poeta", "As asas não the cabem no caixão!", no "Novo Epitáfio para um Poeta" "Na terra nua,/ as asas desdobraram,/ Espigaram,/ Deram flor." ${ }^{11}$ Uma moldura de asas potenciando a ficcionalidade da auto-representação que nela se desenvolverá: a de um Filho do Homem, “Filho do pó, já o próprio pó sou eu .../ Mas, ao terceiro dia, hei de acordar!” ("Imortalidade"). Ecce homo.

Porém, extraordinário que é, "Nascido do amor que há entre Deus e o Diabo"32, não apenas vive a clivagem e a tensão entre os opostos que o geram, mas também é palco onde outra singularidade, a da "Vocação", irrompe, arrastando-o:

Pela noite, esse Grito alevantou-se

Dos mais escusos longes do meu ser E eu compreendi que do teu seio o trouxe, Mãe!, e que me era urgente obedecer (p. 95).

\footnotetext{
${ }^{29}$ Sobre isto, cf. Manuel José Matos Nunes. José Régio, o eu superlativo - o ciclo romanesco " A velha casa "e outros escritos autobiográficos (2013) [http://hdl.handle.net/10362/10378]

30 Op. cit., p. 175

${ }^{31}$ Dos "Epitáfios" de Filho do Homem, Porto, Portugália Editora, 1961.

32 José Régio. Poemas de Deus e do Diabo, Lisboa, Portugália Editora, 1965, p. 52
} 
Biografia (1929) 33 abre com o "Conto" onde se sintetiza e se anuncia o percurso de uma criança marcada por "enigmáticos destinos" (p. 10), insinuando, em referência de fundo a ficção tradicional da nossa infância, o inesquecível "Capuchinho Vermelho" que algumas versões fazem terminar bem e outras não. 0 modo é dramático, teatral, manipulando-me o olhar que foca no início desse percurso, num presente visualizador:

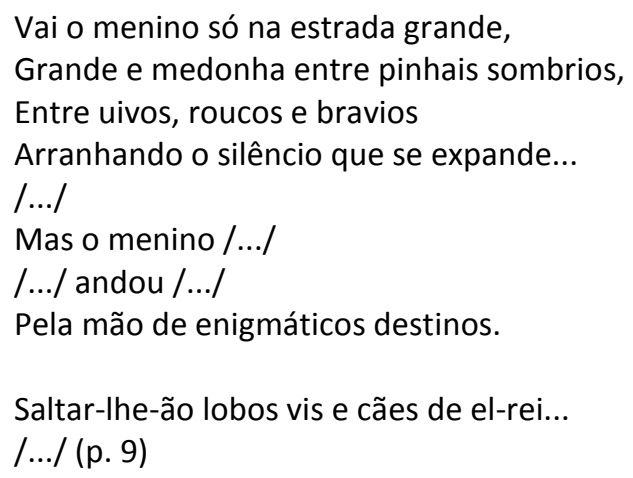

Em "Baptismo", esse "menino" ficcionado é assumido na primeira pessoa, o que confirma a teatralidade da arquitectura poética adiante evidenciada pelo "palco" (p. 40) e pelo "pano" de boca (p. 167):

Foi numa tarde, há muito!, em que eu morria

Como num sonho ansiosamente vago.

Via nuvens fugindo sobre um lago,

Lá num deserto onde o luar nascia (p. 11).

"Génese" confirma essa transformação da terceira pessoa na primeira, encena-a:

Sozinho, à margem do caminho, um verme.

Passam, repassam bandos pela estrada.

E alguns vão vê-lo... ou antes: vêm ver-me,

Com um dó que dói como uma chicotada! (p. 13)

No ritual do baptismo envolvido em indefinição onírica e lunar, definem-se as características do menino, o seu Fado (p. 96): seria poeta (p. 12), "triste" e "sozinho, à margem do caminho" ( $p$ 13), "sufoca[do]" por "qualquer coisa de absurdo", e herda "uma chaga incurável e minaz" (p. 15), "fonte" da sua poesia, "canto" "ritm[ado]" pela "melodia" da "flauta" de um "mago" (p. 11). Em "Vocação", fala desse Fado e do modo como ele se the revelou epifânica e enigmaticamente:

Pela noite, esse Grito alevantou-se Dos mais escusos longes do meu ser, E eu compreendi que do teu seio o trouxe, Mãe!, e que me era urgente obedecer.

33 A edição utilizada foi a das "Obras Completas" da Brasília Editora, 1978. 
Mandava não sei quê...- fosse o que fosse!

Frio e mudo me ergui, todo a tremer...

E o silêncio da noite alvoroçou-se

De vozes que eu ouvi sem compreender.

\section{/.../}

E é de então que, chorando sangue, corro...

/.../voz do meu Fado inatingível,

Fala! E que eu saiba, ao menos, porque morro (pp.95-96).

Perfilam-se, deste modo, imagens construindo-Ihe uma linhagem estética: a solidão do "poeta nato" nobreano e a "chaga" onde molha a pena, o espanto e absurdo de Raúl Brandão, a flauta melancólica de Pessanha, o canto de Camões e muitas outras (Ícaro, Onan, Job, esfinge, Tartufo, Hamlet, etc.)...

Sem Ihe perscrutar essa linhagem que Ihe esteticiza o discurso, destaco três figuras maiores em que o sujeito se verte para melhor se definir:

1) a de "clown":

E um jovem clown azul, contra a vidraça, Paira, sonhando ao som da roda lenta... (p. 17)

2) a de Narciso:

Dentro de mim me quis eu ver. Tremia, Dobrado em dois sobre o meu próprio poço... (p. 19)

3) a de Cristo:

Eis-me... Ecce homo! -, nu, vencido, atado.

Podeis cuspir-me à cara os vossos lodos. (p. 74)

Nessa "paródia de [si] mesmo" (p. 22), essas imagens em movimento realizam uma viagem com etapas e incidentes sinalizados nos títulos dos poemas ("Apeadeiro", "Triunfo", "Logro", etc.), a viagem da vida que só não termina com a própria morte porque a escrita é sua sequência e consequência, a torna matéria sua, "imortalizando" assim o poeta e realizando, afinal, o projecto impossível e perverso da autobiografia, palavra de além-túmulo:

\footnotetext{
Já no lugar dos olhos, que eram belos,

Tenho um buraco atónito e apagado;

Já rosas de gangrena me hão toucado,

Comendo-me as raízes dos cabelos;

/.../

Já milhões de pés vivos me pisaram;

Filho do pó, já o próprio pó sou eu...

Mas, ao terceiro dia, hei-de acordar! (pp. 177-8)
} 
Cada imagem percorre o seu itinerário ao longo da obra, em trajectória que as sobrepõe e mutuamente as fantasmiza. Todas se alternam e se conjugam na tentativa do poeta de melhor se ver e se fazer ver, objectivo da sua escrita. A comparação releva do esforço de aproximação cognoscente e regista-o, fixando-lhe o movimento e a hesitação, as alternativas nunca definitivas, o ensaísmo reflexivo de "Quem /.../ /Se exibe duplo, intolerável, só!" (p. 40). Com a metáfora,

Abrem-se então, no palco, os alçapões...

$\mathrm{O}$ homem cai ao poço. E as multidões

Vão depor loiros murchos no seu pó (p. 40).

A máscara, de palavras feita, oculta o rosto e impõe-se iconicamente a quem o olha, monumento com a densidade do imaginário colectivo. Sob ela, o poeta dissolve-se...

Essas imagens da identidade que o poeta deseja definir, na sua sucessão, acabam por configurar um autêntico "Baile de Máscaras" lembrando o da "máscara insuspeita" de Pessoa ${ }^{34}$ :

Minhas rugas mais fundas que taludes,

Quantas máscaras, já, vos fui colando?

Mas sempre, atrás de Mim, me vou buscando

Meus verdadeiros vícios e virtudes.. (p. 61)

Baile em que o poeta é único actor, encenador, cenógrafo, dramaturgo, narrador, múltiplo, enfim:

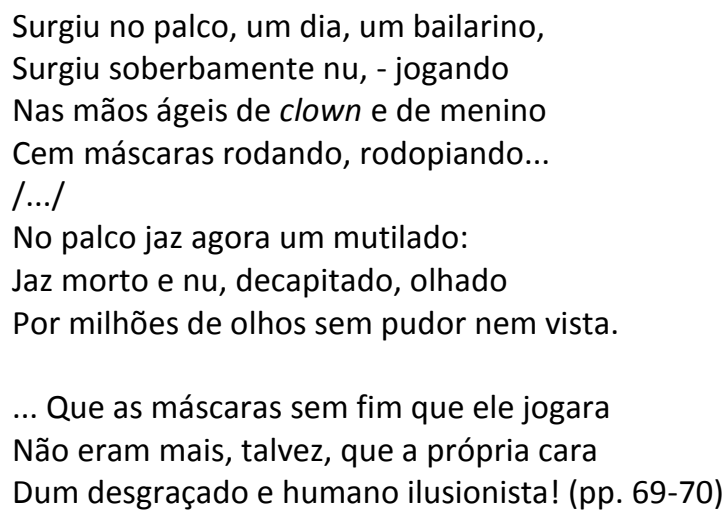

Nele e no que "jaz morto e nu" reconhecemos a problemática pessoana da despersonalização e da heteronímia. "Encoberto" (p. 75) nas brumas da poesia, toma o facho desse "mensageiro" de outrem que em outrem se transforma, fazendo sua a Hora de todos (p. 154). E a história repetese em "desassossego" (p. 93) e n'As Encruzilhadas de Deus (1936), entre a fé ("Eis como sou! Isto sou!,/ Sou esta Torre truncada...! / Que o Anjo que me expulsou, / Quando Deus me renegou

34 "Eu sou o disfarçado, a máscara insuspeita. / Entre o trivial e o vil m[inha] alma insatisfeita / Indescoberta passa /.../" (Teresa Rita Lopes. Pessoa por Conhecer - Textos para um Novo Mapa, Lisboa: Estampa, 1990, p. 92.) [http://arquivopessoa.net/textos/771]. 
/ Na porta que se fechou / Tal como sou me desenhou / Com fogo da sua espada...") e a heresia ("Senhor meu Deus em que não creio, porque és minha criação!/ (Deus, para mim, sou eu chegado à perfeição...)", com diz no "Poema do Silêncio"35)

O procedimento citacional molda e conforma a imagística do texto, multiplicando-a e conferindo-Ihe redundância interna, continuidade, tece-o de outros que, por sua vez, de memória literária e mitológica são tecidos... num imenso dialogismo expandido em círculos concênctricos cada vez mais difusos, mas perceptíveis.

Creio poder afirmar que a Biografia regiana, no jogo de transparências e de sobreposições em que as figuras literárias, mitológicas, etc. se fantasmizam, constitui uma autobiografia dramaticamente elaborada onde a identidade se busca na alteridade e se fragmenta em duplicidades. Mas também vejo nela o ensaio de uma biografia simbólica do sopro poético que atravessa o tempo reencarnando em cada verbo que a Literatura foi fazendo seu, do grito que, de eco em eco, se vai "modula[ndo]" "em melodia" (p. 151), cristalizando na palavra e "vibra[ndo]" no poema. Universal, portanto, no sentido mais rigoroso e mais amplo do termo:

Uma aragem de Além passou nos ares, Beijou-me a fronte.../.../ (p. 127)

"Aragem de Além", sopro que é "o vento perpassando, baixo e esquivo,/Do chão levanta[ndo] uns sons de velhas árias..." (p. 31) e gerando um canto polifónico de remotas e obscuras origens. O "eu que nunca principio nem acabo" enunciado no "Cântico Negro".

Biografia espiritual que se renova no tempo, confirmada na história, concretizada nos nomes, denunciada nas obras, cartografada na opacidade da palavra poética: una e única na diversidade das circunstâncias e das identidades, sempre a mesma em "bana[is] cenário[s]" que se "desfazem" (p. 132). Um ciclo padronizando a vibração do signo poético. Daí uma escrita que, retomando outras, "Segue no próximo número" (pp. 179/180), como o afirma no título do último poema. Daí o enigmático final:

\section{Venho e vou...! venho e vou...!, sempre! E é inútil Querer vestir qualquer paragem fútil, Que o tal aceno incógnito é mais forte... (p. 180)}

E Régio parece movido pel' "o sopro, a aragem - ou desgraça ou ânsia - , / Com que a chama do esforço se remoça" que Pessoa assinala na "Prece"36 da sua Mensagem (1936), anelante de sonho e utopia incumpridos que a Bela Adormecida ("Versos da Bela Adormecida") lhe sugere:

\footnotetext{
${ }^{35} \mathrm{Cf}$. https://www.pensador.com/frase/NzU1NDYw/.

${ }^{36} \mathrm{Cf}$. http://arquivopessoa.net/textos/92.
} 
Lá longe, muito longe, ai, muito longe!, ao fundo

De areias e gelos do cabo do mundo,

Depois de ralos, aflições, suores, dragões, ciladas, perigos,

E bosques tenebrosos, antigos, antigos.

Sonhei que ela me espera, adormecida

Desde o começo da vida,

Nua, deitada sobre as tranças de oiro,

Guardada para mim como um tesoiro.

Sonhei que um nimbo argênteo a veste,

Raiando o céu de norte a sul, de leste a oeste,

E que sobre ela paira o silêncio profundo

Dos gelos e areias do cabo do mundo...

No seu lábio, um sorriso ainda transido

Ficou, como na boca das estátuas, esculpido,

Esperando, talvez, para raiar,

Que ela suba as pestanas, devagar... ${ }^{37}$

Vi uma vez, em sonhos vi, que aquelas pálpebras se erguiam,

Sim, devagar..., sim, devagar..., e que os seus lábios me diziam,

Estendidos para mim:

- "Chegaste?, chegaste enfim?!"

Sonho, pois, apenas sonho, como reconhece agonicamente ao despertar:

Foi isto em sonhos. Acordado, eu perguntava: - "Que farei?"

$$
\text { l... }
$$

Assim falei. Ninguém, porém, me mostrou ter ouvido.

Meu grito, além, se extinguiu já, perdido...

E eu morro deste ardor, que nada acalma,

Com que aspiro debalde à minha própria alma. ${ }^{38}$

A tragicidade do episódio desenvolve-se em diálogo assimétrico com o do pessoano

"Eros e Psique", concluído no encontro de desvelada surpresa, que Maria Betânia tão bem disse ${ }^{39}$ :

Conta a lenda que dormia

Uma Princesa encantada

A quem só despertaria

Um Infante, que viria

De além do muro da estrada

/.../

Mas cada um cumpre o Destino -

Ela dormindo encantada,

Ele buscando-a sem tino

Pelo processo divino

Que faz existir a estrada.

37 José Régio. As Encruzilhadas de Deus (1936).

38 https://novasilva.blogs.sapo.pt/versos-da-bela-adormecida-481261.

${ }^{39} \mathrm{https}: / /$ www.youtube.com/watch?v=oyp6bjFSzA8 

$E$, se bem que seja obscuro
Tudo pela estrada fora,
E falso, ele vem seguro,
$E$, vencendo estrada e muro,
Chega onde em sono ela mora.
$E$, inda tonto do que houvera,
À cabeça, em maresia,
Ergue a mão, e encontra hera,
E vê que ele mesmo era
A Princesa que dormia. ${ }^{40}$

“Cai o Pano" (pp. 167-8) sobre este verbo. Subirá de novo para o que se lhe segue. Até lá, resta-nos a imagem do Poeta, esvaziado de vida e anelante dela, em rigidez granítica e expectante, memória e anseio da "Visitação da tarde", signo aguardando que "O sol fund[a] em oiro a névoa fria" e "Num banho de oiro, a terra jaz[a], prostrada" (p. 57) para ser habitado de novo e mais uma vez vibrar esteticamente:

O arcanjo de asas pandas de granito Poisa um dedo no lábio concentrado; Mantém-se hierático e de pé, gelado; E o seu olhar de pedra é alheio e fito.

("Epitáfio do poeta", p. 175)

Epitáfio deste poeta e legenda do que se Ihe segue.

Dedicatória em ano de outro centenário:

A Amália Rodrigues (1920-99), nesta revisitação regiana ao fado português. Juntando-me aos que a celebram em revisitação regiana.

${ }^{40} \mathrm{http}: / /$ arquivopessoa.net/textos/4265 